\title{
Tingkat Kepedulian pada Implementasi Sistem Drainase Sesuai dengan Zero Delta $Q$ dan Faktor Keberhasilannya pada Pengembangan Apartemen Di Surabaya
}

\author{
Dea Deliana ${ }^{1, *}$, Christiono Utomo ${ }^{1, *}$ \\ Departemen Teknik Sipil, ITS, Surabaya ${ }^{1}$ \\ Koresponden*, Email: dea276@gmail.com,christionoutomo@gmail.com
}

\begin{tabular}{l}
\multicolumn{1}{c}{ Info Artikel } \\
\hline Diajukan 28 Juli 2017 \\
Diperbaiki 6 Desember 2017 \\
Disetujui 7 Desember 2017
\end{tabular}

Keywords: drainage, the success of principles $Z D Q$ for apartements, the awareness level.

\begin{abstract}
Interelated drainage by flooding depends on the planning, operation and maintenance. Flooding is a problem that always faced by the city of Surabaya, and therefore the need to curb the impacts of development. Developer as population and sample of the research respondents are stakeholders in development and has an important role to realize the above. This research is purpose to determine the level of awareness and analyzing the success factors as well as the implementation of the drainage system by the actors, especially the construction of apartments. The method used in the analysis is the analysis of factors. The analysis it self will become a benchmark for successful implementation of the drainage system in accordance with the principle of zero delta $Q(Z D Q)$ contained in the Government Regulation (PP) 26 of the Spatial Territory City Plan of 2008. The results of those responsible for the level of awareness in the construction of apartment developer located in Surabaya, has developed and implemented the system and proper drainage of the building, although not knowing the principles of $Z D Q$. The results showed that the obtained three factors consisting of drainage management factors that give the effect of $52 \%$, management planning \& planning factors that influence the success of the design by $15 \%$, and the last is the commitment factor has contributed to the success of $13 \%$.
\end{abstract}

Keterkaitan drainase dengan banjir tergantung pada perencanaan, pengoperasian, dan pemeliharaannya. Banjir merupakan permasalahan yang selalu dihadapi oleh kota Surabaya, maka dari itu perlu penertiban dampak-dampak dari pembangunan. Developer sebagai populasi dan sampel dari responden penelitian ini merupakan pemangku kepentingan pada pembangunan dan memiliki peran penting untuk mewujudkannya. Penelitian ini bertujuan untuk mengetahui tingkat kepedulian dan menganalisis faktor keberhasilan serta penerapan sistem drainase oleh para pelaku konstruksi khususnya apartemen. Metode yang digunakan dalam menganalisis adalah analisis faktor. Adapun Analisis ini akan menjadi tolak ukur berhasilnya penerapan sistem drainase yang sesuai dengan prinsip Zero Delta $Q$ (ZDQ) yang terdapat pada Peraturan Pemerintah (PP) No.26 menegenai Rencana Tata Ruang Wilayah tahun 2008. Hasil tingkat kepedulian para penanggung jawab konstruksi di developer apartemen yang berada di Surabaya yaitu telah membuat dan melaksanakan sistem dan bangunan drainase secara tepat walaupun tidak mengetahui prinsip-prinsip ZDQ. Hasil penelitian menunjukkan bahwa didapatkan 3 faktor terdiri dari faktor pengelolaan drainase memberikan pengaruh sebesar $52 \%$, faktor perencanaan pengelolaan \& perencanaan desain memberikan pengaruh keberhasilan sebesar $15 \%$, dan faktor komitmen telah memberikan pengaruh keberhasilan sebesar $13 \%$.
Kata kunci: Drainase, keberhasilan prinsip ZDQ untuk apartemen, tingkat kepedulian.
Kota yang merujuk pada pasal 106 dan 99, Kebijakan Zero Delta Q disarankan menjadi tolak ukur keberhasilan penerapan sistem drainase kawasan yang telah direncanakan pada kajian drainasenya [2]. Kebijakan Zero Delta Q (ZDQ) merupakan sebuah konsep "awas banjir" dengan menerapkan pembatasan limpasan air akibat pembangunan dimana selisih antara debit limpasan air sebelum pembangunan dan sesudah pembangunan harus 0 (nol).

Sejalan dengan perkembangan pembangunan apartemen di wilayah Surabaya, terjadi perubahan lahan menjadi daerah permukiman yang tentunya berdampak pada besarnya limpasan air yang menuju saluran drainase. Perkembangan apartemen tersebut belum didukung sepenuhnya oleh perkemba- 
ngan peningkatan kapasitas drainase, sehingga menjadi masalah tersendiri dalam pengelolaan sistem drainase [3]. Badan Perencanaan Pembanguan Kota Surabaya menyusun Surabaya Drainage Masterplan (SDMP) 2018 sebagai upaya untuk mengurangi banjir di Surabaya. SDMP 2018 dimaksudkan untuk mengurangi beban infrastruktur drainase yang ada dengan dilakukan pengendalian pembangunan sesuai dengan Rencana Tata Ruang dan Master Plan drainase yang ada. Hal tersebut salah satunya menetapkan bahwa setiap pemba-ngunan hunian baru harus mempertimbangkan perubahan limpasan permukaan seminim mungkin dan memiliki infrastruktur drainase yang memadai.

Berdasarkan uraian di atas maka penelitian ini dilakukan untuk mengidentifikasi tingkat kepedulian serta menganalisis faktor-faktor apa saja yang mempengaruhi keberhasilan penerapan kajian drainase dalam pembangunan apartemen di Surabaya yang sesuai dengan prinsip Zero Delta $Q$ policy agar dapat menjadi upaya dalam mengurangi banjir di Kota Sura-baya. Tingkat kepedulian perlu diukur untuk mengetahui seberapa besar kepedulian para pelaku pengembang kon-struksi terhadap dampak lingkungan yang ditimbulkan dalam pembangunan apartemen khususnya mengenai genangan air dan banjir yang dapat disebabkan.

Penelitian ini ditujukan bagi para pelaku pengembang konstruksi yang ada di Surabaya yang akan difokuskan pada objek pembangunan apartemen. Pada penelitian ini diharapkan dapat diperoleh informasi kepedulian para pengembang konstruksi dan keterlibatannya untuk mengurangi banjir di Surabaya, untuk referensi parameter keberhasilan upaya-upaya dalam mewujudkan integrasi tata ruang-tata air serta lingkungan hidup yang menjadi landasan Surabaya Drainage Master Plan 2018.

\section{Metode}

Berdasarkan latar belakang, maka penelitian ini menggunakan jenis penelitian eksploratif. Penelitian eksploratif yaitu penelitian yang dilaksanakan untuk menggali data dan informasi tentang topik atau isu-isu baru yang ditujukan untuk kepentingan pendalaman atau penelitian lanjutan.

Analisis faktor pada tabel 1 digunakan untuk mengelompokkan beberapa variabel yang memiliki kemiripan untuk dijadikan satu faktor. Kemiripan tersebut ditunjukan dengan nilai korelasi yang tinggi sehingga akan membentuk satu kerumunan faktor. Prinsip dasar analisis faktor adalah menye-derhanakan deskripsi tentang data dengan mengurangi jumlah variabel/dimensi. Langkah-langkah analisis faktor adalah sebagai berikut [4]:

a. Merumuskan masalah (menentukan tujuan yang ingin dicapai), b. Membentuk matriks korelasi antar variabel,

c. Melakukan pengujian terhadap matriks korelasi antar variabel dengan tiga statistik yaitu uji Kaiser Meyer Oikin (KMO) bertujuan untuk mengetahui apakah semua data yang terambil telah layak untuk analisis faktor, uji Barlett bertujuan untuk mengetahui apakah terdapat hubungan antar variabel, dan uji Measures of Sampling Adequacy (MSA) bertujuan untuk mengetahui kecukupan data atau sampel. Klasifikasi nilai $\mathrm{KMO}$ adalah $\leq 0,50=$ tidak diterima, 0,50 - 0,59 = buruk, 0,60 - 0,69 = cukup, 0,70 $-0,79=$ biasa, $0,80-0,89=$ berguna dan $\geq 0,9=$ sangat baik. Untuk nilai Barlett test memiliki signifikan lebih besar dari alfa sedangkan untuk variabel yang memiliki nilai MSA $<0,55$ direduksi dari Analisis factor,

Tabel 1. Operational Definitions of Success Variable Drainage System

\begin{tabular}{|c|c|c|}
\hline $\begin{array}{c}\text { Sub } \\
\text { Faktor }\end{array}$ & Indikator & Def inisi Operasional \\
\hline \multirow{11}{*}{$\begin{array}{l}\text { Kinerja } \\
\text { sistem } \\
\text { drainase }\end{array}$} & $\begin{array}{l}\text { Kepahaman Mengenai } \\
\text { Karakteristik Masalah } \\
\text { yang Ditemui (I1) }\end{array}$ & $\begin{array}{l}\text { Mengetahui dan menyebutkan } \\
\text { permasalahan yang didadapi } \\
\text { saat sebelum dan saat } \\
\text { pelaksanaan }\end{array}$ \\
\hline & $\begin{array}{l}\text { Kepahaman Mengenai } \\
\text { Kebijakan atau } \\
\text { Peraturan yang Ada } \\
\text { (I2) }\end{array}$ & $\begin{array}{l}\text { Mengetahui dan menyebutkan } \\
\text { kebijakan dan peraturan yang } \\
\text { terkait perencanaan drainase }\end{array}$ \\
\hline & $\begin{array}{l}\text { Adanya komitmen } \\
\text { dalam menjaga } \\
\text { Lingkungan } \\
\text { Implementasi (I3) }\end{array}$ & $\begin{array}{l}\text { Memiliki upaya untuk menjaga } \\
\text { kualitas lingkungan sekitarnya }\end{array}$ \\
\hline & $\begin{array}{l}\text { Kesesuaian } \\
\text { Perencanaan Sistem } \\
\text { Drainase (I4) }\end{array}$ & $\begin{array}{l}\text { Perencanaan dan pelaksanaan } \\
\text { dan pengoperasian yang sesuai } \\
\text { dengan kajian drainase yang } \\
\text { dibuat sebelumnya }\end{array}$ \\
\hline & $\begin{array}{l}\text { Terdapatnya Prosedur } \\
\text { PEngelolaan Sistem } \\
\text { Drainase (I5) }\end{array}$ & $\begin{array}{l}\text { Memiliki standar operating } \\
\text { procedure } \quad \text { (SOP) dalam } \\
\text { pengelolaan sistem drainase }\end{array}$ \\
\hline & Ketersediaan & Memiliki badan pengelola \\
\hline & $\begin{array}{l}\text { Pengelola Sistem } \\
\text { Drainase (I6) }\end{array}$ & $\begin{array}{l}\text { drainase dalam bagan } \\
\text { organisaasinya }\end{array}$ \\
\hline & $\begin{array}{l}\text { Frekuensi Evaluasi } \\
\text { Sistem Drainase (I7) }\end{array}$ & $\begin{array}{l}\text { Menjadwalkan evaluasi sistem } \\
\text { drainase secara berkala }\end{array}$ \\
\hline & Ketersediaan & Memiliki bangunan drainase \\
\hline & $\begin{array}{l}\text { Bangunan Drainase } \\
\text { dan Fasilitas } \\
\text { Pelengkapnya (I8) }\end{array}$ & $\begin{array}{l}\text { yang dapat mengalirkan serta } \\
\text { menampung limpasan air, serta } \\
\text { fasiitas pendukungnya }\end{array}$ \\
\hline & $\begin{array}{l}\text { Frekuensi } \\
\text { Pemeliharaan } \\
\text { Bangunan Drainase } \\
\text { (I9) }\end{array}$ & $\begin{array}{l}\text { Melakukan pemeliharaan dan } \\
\text { perawatan bangunan drainase } \\
\text { secara berkala }\end{array}$ \\
\hline \multirow[t]{2}{*}{$\begin{array}{l}\text { Kinerja } \\
\text { Bangunan } \\
\text { drainase }\end{array}$} & $\begin{array}{l}\text { Kelancaran Sistem } \\
\text { Drainase (I10) }\end{array}$ & $\begin{array}{l}\text { Setelah memenuhi syarat-syarat } \\
\text { sistem drainase yang ada serta } \\
\text { melakukan pengelolaan dan } \\
\text { pemeliharaan yang benar maka } \\
\text { seharusnya tidaak ada lagi } \\
\text { banjir atau genangan air di } \\
\text { wilayah sekitarnya }\end{array}$ \\
\hline & $\begin{array}{l}\text { Tersedianya Anggaran } \\
\text { Biaya (I11) }\end{array}$ & $\begin{array}{l}\text { Menyediakan biaya yang telah } \\
\text { dianggarkan sebelumnya untuk } \\
\text { keperluan perencanaan, } \\
\text { pembuatan, pengoperasian dan } \\
\text { pemeliharaannya }\end{array}$ \\
\hline
\end{tabular}


d. Melakukan ekstraksi faktor yang bertujuan untuk mengetahui jumlah yang faktor terbentuk dari data yang ada. Metode yang digunakan adalah Analisis Komponen Utama (Principal Components Analysis),

e. Melakukan rotasi faktor yang bertujuan untuk memperoleh struktur faktor yang lebih sederhana agar mudah diinterpretasikan.

f. Menginterpretasikan hasil dari penelitian

\section{Hasil dan Pembahasan \\ Profil Responden}

Populasi dalam penelitian ini adalah para penanggung jawab sistem drainase di developer apartemen yang berada di wilayah Surabaya. Sampel yang akan diambil dalam penelitian ini yaitu para project manager dan engineering dibagian MEP (Mechanical Electrical Plumbing) yang pernah dan/atau sedang bertanggung jawab dalam sistem drainase di developer apartemen di Surabaya.

Tabel 2. Respondents Profiles

\begin{tabular}{llcc}
\hline No & Deskripsi & $\begin{array}{c}\text { Total } \\
\text { Responden }\end{array}$ & $(\%)$ \\
\hline $1 . \quad$ & Respondent & 30 & 100 \\
& Position & & \\
2. $\quad$ 1. Engineer & 11 & 36,7 \\
& 2. Project Manager & 19 & 63,3 \\
& Sub total & 30 & 100 \\
& Long time working in & & \\
$\quad$ Surabaya: & 12 & 40 \\
3. $\quad$ 1. -5 years & 9 & 30 \\
& 2. 5-10 years & 9 & 30 \\
& 3. > 10 years & 30 & 100 \\
& Sub total & & \\
& Year Apartment was built : & & \\
4 & S2010 & 2 & 6,7 \\
& $>2010$ & 28 & 93,3 \\
& Sub total & 30 & 100 \\
\hline
\end{tabular}

(Sumber : Hasil Analisis)

Dari data pada tabel 2 bisa dijelaskan bahwa apartemen yang banyak menjadi sampel peneliti yaitu apartemen yang dibangun pada tahun > 2010, karena prinsip kebijakan Zero Delta $Q$ (ZDQ) dikeluarkan oleh Pemerintah Pusat pada tahun 2008 dalam PP No. 26 mengenai Rencana Tata Ruang Wilayah. Perbedaan responden pada penelitian ini didapatkan karena setiap proyek apartemen memiliki narasumber terkait drainase yang berbeda-beda.

\section{Analisis Tingkat Kepedulian}

Data analisis tingkat kepedulian ini bertujuan untuk mengetahui persepsi dan jumlah responden mengenai variabel awareness. Dalam menentukan tingkat kepedulian seseorang, ada dua dimensi yang diukur yaitu pengetahuan dan sikap. Pada tabel 3 ditunjukkan perhitungan nilai mean dan standar deviasi.

Gambar 1 merupakan nilai rata-rata (mean) pada indikator tingkat kepedulian (awereness), dimana semakin besar nilai rata-ratanya maka persepsi tingkat persetujuan responden semakin kuat. Sedangkan sumbu Y merupakan nilai varian atau standar deviasi dari masing-masing pernyataan tersebut, semakin kecil nilai standar deviasi maka sebagian responden sepakat jawaban tersebut dan sebaliknya.

Pada indikator Rasa Tahu dan Pemahaman menunjukkan bahwa rata-rata responden tidak mengetahui dan memahami sistem drainase yang sesuai dengan prinsip Zero Delta $Q$ (ZDQ). Akan tetapi responden cenderung mengetahui secara umum mengenai sistem drainase yang baik, cara pengaplikasiannya serta sebab akibatnya jika tidak melaksanakan rencana sistem drainase tersebut dengan tepat. Afektif yang memiliki nilai rata-rata (mean) mendekati angka 5, walaupun nilai standar deviasinya menjauhi angka 0 untuk indikator Afektif. Hal tersebut bisa dikarenakan tolak ukur pengalaman tiap responden yang berbeda dalam menangani sistem drainase apartemennya.

Tabel 3. Mean and sd Values of Concern

\begin{tabular}{cccc}
\hline Variabel & Indikator & Mean & $\begin{array}{c}\text { Standar } \\
\text { Deviasi }\end{array}$ \\
\hline Pengetahuan & Rasa tahu & 2,4 & 1,192 \\
& Pemahaman & 2,7 & 1,368 \\
& Mengaplikasikan & 4,858 & 0,7205 \\
Sikap & Analisis & 4,5 & 0,601 \\
& Cognitive & 4,267 & 0,772 \\
& Affactive & 3,97 & 1,159 \\
\hline
\end{tabular}

(Sumber : Hasil Analisis)

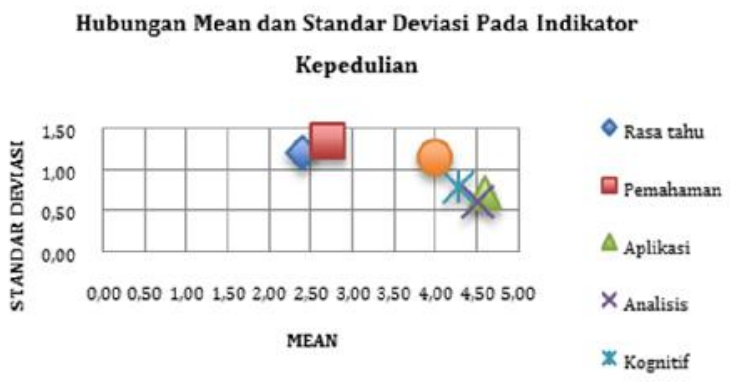

Gambar 1. Grafik hubungan mean dan standar deviasi. (Sumber : Hasil Analisis) 
Peraturan atau regulasi yang mengatur sistem drainase di Surabaya telah diatur dalam Surabaya Drainage Master Plan (SDMP) yang konsepnya mengadaptasi dari prinsip Zero Delta $Q$ (ZDQ). Kebijakan dari setiap developer dalam pembangunan sistem drainase dalam sebuah apartemen dapat diwakilkan oleh seorang Project Manager, MEP atau pejabat kepentingan dalam proyek yang memiliki andil dalam pembuatan keputusan atau kebijakan dalam pembangunan apartemen. Dalam penelitian yang telah dilakukan mengenai tingkat kepedulian dalam implemantasi sistem drainase sesuai dengan prinsip ZDQ, disimpulkan bahwa para stakeholder pembangunan apartemen sudah peduli akan pembuatan sistem drainase yang memadai dengan fasilitas yang baik untuk mencegah banjir dan genangan air. Akan tetapi, dalam penelitian ini ditemukan bahwa para stakeholder pembangunan apartemen ini tidak mengetahui dan memahami istilah Zero Delta Q dari sistem dan bangunan drainase yang mereka bangun. Akan tetapi meskipun istilah ZDQ ini tidak awam di telinga para stakeholder tetapi dari beberapa aspek yang diukur dalam tingkat kepedulian ini, hal-hal dalam prinsip ZDQ terkait kelengkapan teknis dalam pembangunan sistem drainase telah dipenuhi oleh setiap stakeholder.

\section{Analisis Faktor}

Analisis yang akan digunakan adalah $\mathrm{R}$ faktor untuk melihat korelasi antara variabel kemudian dilakukan data reduction untuk menghasilkan variabel baru yang mencakup beberapa variabel set. Ke-11 variabel (dalam penelitian ini disebut indikator) yang menjadi penentu keberhasilan implementasi sistem drainase tersebut akan diuji apakah semuanya menjadi variabel penting atau hanya sebagian saja yang layak untuk dianalisis dan dikelompokan menjadi faktor utama.

Tabel 4. KMO and Bartlett's Test

\begin{tabular}{llr}
\hline Kaiser-Meyer-Olkin Measure of Sampling Adequacy. & .761 \\
& Approx. Chi-Square & 119.827 \\
Bartlett's Test of Sphericity & df & 28 \\
& Sig. & .000 \\
\hline Sumber $:$ Hasil Analisis &
\end{tabular}

Hasil output pada tabel 4 menunjukkan nilai KMO adalah 0,761 . Besarnya korelasi antara independent variabel (indikator) yang diukur memiliki nilai KMO-MSA diatas 0,5 hal ini menunjukan bahwa signifikan dan dapat diproses lebih lanjut. Pada tabel 5, bagian initial eigenvalues dikolom total, ada 3 angka yang memiliki nilai lebih besar dari satu, artinya hanya ada tiga faktor yang terbentuk.
Tabel 5. Total Variance Explained

\begin{tabular}{|c|c|c|c|c|c|c|c|c|c|}
\hline \multirow[b]{2}{*}{ Component } & \multicolumn{3}{|c|}{ Initial Eigenvalues } & \multicolumn{3}{|c|}{ Extraction Sums of Squared Loadings } & \multicolumn{3}{|c|}{ Rotation Sums of Squared Loadings } \\
\hline & Total & $\begin{array}{c}\% \text { of } \\
\text { Variance }\end{array}$ & \begin{tabular}{|c} 
Cumulative \\
$\%$
\end{tabular} & Total & \begin{tabular}{c|}
$\%$ of \\
Variance
\end{tabular} & Cumulative \% & Total & $\begin{array}{c}\% \text { of } \\
\text { Variance }\end{array}$ & Cumulative \% \\
\hline 1 & 4.168 & 52.097 & 52.097 & 4.168 & 52.097 & 52.097 & 2.437 & 30.460 & 30.460 \\
\hline 2 & 1.200 & 14.995 & 67.093 & 1.200 & 14.995 & 67.093 & 2.236 & 27.950 & 58.410 \\
\hline 3 & 1.036 & 12.953 & 80.046 & 1.036 & 12.953 & 80.046 & 1.731 & 21.636 & 80.046 \\
\hline 4 & .534 & 6.680 & 86.726 & & & & & & \\
\hline 5 & .436 & 5.453 & 92.180 & & & & & & \\
\hline 6 & .317 & 3.963 & 96.143 & & & & & & \\
\hline 7 & .160 & 2.002 & 98.145 & & & & & & \\
\hline 8 & .148 & 1.855 & 100.000 & & & & & & \\
\hline
\end{tabular}

(Sumber : Hasil Analisis)

\section{Faktor Pertama}

Dalam pengelolaan sistem dan bangunan drainase membutuhkan sumber daya manusia (pengelola) yang dapat mengoperasikan serta mengontrol kinerja dan fungsi dari sistem bangunan drainase itu sendiri, perhitungan bukaan pintu air atau jadwal pengosongan kolam tampungan harus sudah dibuat sebelumnya dan disertakan dalam Standar Operasi Prosedur yang ada [5]. Sistem drainase bisa berubah sesuai dengan kebutuhannya, dilihat dari kapasitas alir dan tampungnya, sistem drainase harus dapat beradaptasi dengan perubahan limpasan ataupun tampungan, berbeda dengan bangunan drainase dan pelengkapnya, evaluasi pada sistem drainase ini lebih fleksibel untuk dirubah terutama jika bangunan sistem drainase tersebut dilengkapi dengan pintu air [6]. Drainase memiliki banyak fungsi, diantaranya: (1) Mengeringkan daerah becek dan genangan air. (2) Mengendalikan akumulasi limpasan air hujan yang berlebihan, (3) Mengendalikan erosi, kerusakan jalan dan kerusakan infrastruktur, dan (4) Mengelola kualitas air. Yang kemudian dinamakan sub faktornya adalah tolak ukur fungsi drainase. Gambar 2 adalah ilustrasi penamaan dari indikator-indikator pada faktor satu.

Tabel 7. Rotated Component Matrix

\begin{tabular}{|c|c|c|c|}
\hline & \multicolumn{2}{|c|}{ Component } & \multirow[b]{2}{*}{3} \\
\hline & 1 & 2 & \\
\hline I1 & .095 & .866 & .020 \\
\hline I3 & .028 & .326 & .852 \\
\hline I4 & .377 & .774 & .184 \\
\hline I5 & .274 & .799 & .391 \\
\hline I7 & .878 & .246 & .214 \\
\hline I9 & .386 & .011 & .824 \\
\hline $\mathrm{I} 10$ & .706 & .240 & .304 \\
\hline I6 & .890 & .159 & .030 \\
\hline \multicolumn{4}{|c|}{$\begin{array}{l}\text { Extraction Method: Principal Component Analysis. } \\
\text { Rotation Method: Varimax with Kaiser Normalization. } \\
\text { a. Rotation converged in } 5 \text { iterations. }\end{array}$} \\
\hline
\end{tabular}

(Sumber : Hasil Analisis) 
Tabel 8 Factor Analysis Results

\begin{tabular}{|c|c|c|c|}
\hline Factor & Code & Indicator & $\begin{array}{l}\text { Loading } \\
\text { factor }\end{array}$ \\
\hline \multirow{3}{*}{1} & I6 & $\begin{array}{l}\text { Availability of drainage } \\
\text { system manager }\end{array}$ & 0,89 \\
\hline & I7 & $\begin{array}{l}\text { Frequency Evaluation of } \\
\text { drainage system }\end{array}$ & 0,878 \\
\hline & I10 & Smooth Drainage System & 0,706 \\
\hline \multirow{3}{*}{2} & I1 & $\begin{array}{l}\text { An understanding of the } \\
\text { characteristics of the } \\
\text { problems encountered }\end{array}$ & 0,866 \\
\hline & I4 & $\begin{array}{l}\text { Conformity of drainage } \\
\text { system planning }\end{array}$ & 0,774 \\
\hline & I5 & $\begin{array}{l}\text { There is a drainage system } \\
\text { management procedure }\end{array}$ & 0,799 \\
\hline \multirow[t]{2}{*}{3} & I3 & $\begin{array}{l}\text { A commitment to maintain the } \\
\text { environment }\end{array}$ & 0,852 \\
\hline & I9 & $\begin{array}{l}\text { Frequency of maintenance of } \\
\text { drainage building }\end{array}$ & 0,824 \\
\hline
\end{tabular}

(Sumber : Hasil Analisis)

Faktor Pelaksanaan Pengelolaan Drainase menjadi faktor pertama dari faktor-faktor keberhasilan implementasi sistem drainase sesuai prinsip ZDQ pada pengembangan apartemen di Surabaya. Hal tersebut dipengaruhi oleh prioritas dari penanggung jawab sistem drainase di developer di Surabaya dalam melihat aspek paling penting yang harus diperhatikan.

\section{Faktor Kedua}

Faktor kedua yang pada penelitian ini menjelaskan bahwa 14,995\% Kepahaman mengenai karakteristik masalah yang akan ditemui. Pada dasarnya setiap pemangku kepentingan (stakeholder) dalam sebuah organisasi harus secara jelas memahami permasalahan-permasalahan yang akan timbul di setiap keputusan yang di ambil. Konsistensi dan ketepatan visi dan misi akan membantu dalam mencapai tujuan [7]. Kesesuaian desain bangunan dan sistem drainase berarti meminimalisir berlebihannya tampungan serta limpasan berkala akibat dari pembangunan apartemen tersebut. Bangunan drainase adalah bangunan infrastruktur yang memiliki beberapa persyaratan teknis, sehingga kelancaran sistem jaringan drainase sangat dipengaruhi oleh perumusan gagasan dan perencanaan teknis [7]. Setiap pengoperasian suatu sistem sebaiknya disertai dengan prosedur pengelolaannya atau biasa disebut dengan Standar Operasional Prosedur (SOP). Kejelasan prosedur pengelolaan akan memudahkan pengelola dalam mengoperasikan sistemnya [5]. Gambar 3 adalah ilustrasi penamaan dari indikator-indikator pada faktor dua.

Penamaan faktor kedua adalah Perencanaan Desain dan Pengelolaan. Pada perencanaan desain, setiap pembangunan apartemen di Surabaya wajib membuat kajian drainase. Salah satu isi dari kajian tersebut adalah perencanaan desain sistem dan bangunan drainase serta rencana pengelolaannya. Kajian drainase tersebut mengadaptasi prinsip dari Zero Delta $Q$, dimana pengembang harus membuat sistem yang seefektif mungkin dengan tidak melebihi kapasitas tampung saluran kota seperti sebelum adanya pembangunan apartemen tersebut. Sistem pengelolaan drainase secara konvensional pada setiap apartemen yang tidak sesuai prinsip ZDQ biasanya membuang limpasan air ke saluran kota melebihi kapasitas yang seharusnya, hal ini bisa menyebabkan kelebihan kapasitas pada saluran kota.

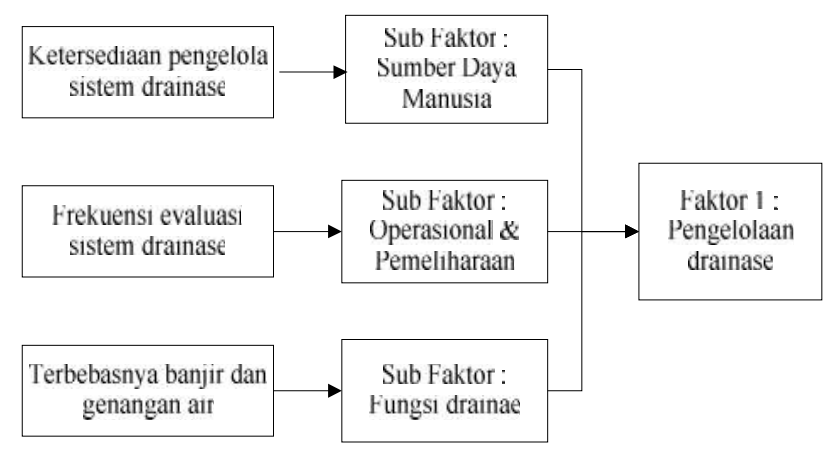

Gambar 2. Skema alur penamaan faktor 1 Sumber : Hasil Analisis

\section{Faktor Ketiga}

Faktor ketiga menjelaskan bahwa 12,953\% Komitmen untuk memelihara lingkungan sekitar diperlukan, karena dengan dibangunnya apartemen maka diharapkan tidak mengganggu kualitas ekologi dan lingkungan sekitarnya. Kegiatan pembangunan yang makin meningkat mengandung resiko pencemaran dan perusakan lingkungan hidup sehingga struktur dan fungsi dasar ekosistem yang menjadi penunjang kehidupan dapat rusak [8]. Komitmen untuk memelihara lingkungan sekitar diperlukan, karena dengan dibangunnya apartemen maka diharapkan tidak mengganggu kualitas ekologi dan lingkungan sekitarnya. Kegiatan pembangunan yang makin meningkat mengandung resiko pencemaran dan perusakan lingkungan hidup sehingga struktur dan fungsi dasar ekosistem yang menjadi penunjang kehidupan dapat rusak[8]. Pemeliharaan bangunan drainase harus dilakukan secara berkala dan pengecekannya harus memperhatikan aspek-aspek teknis pada bangunan drainase tersebut karena hal itu berkaitan dengan kinerja (daya alir dan daya tampung) sebuah bangunan drainase. Frekuensi pengecekan dan pemeliharaan suatu bangunan draianse disesuaikan dengan kebutuhan dan kondisi pemakaian bangunan drainase tersebut [6]. Gambar 4 adalah ilustrasi penamaan dari indikator-indikator pada faktor tiga. 


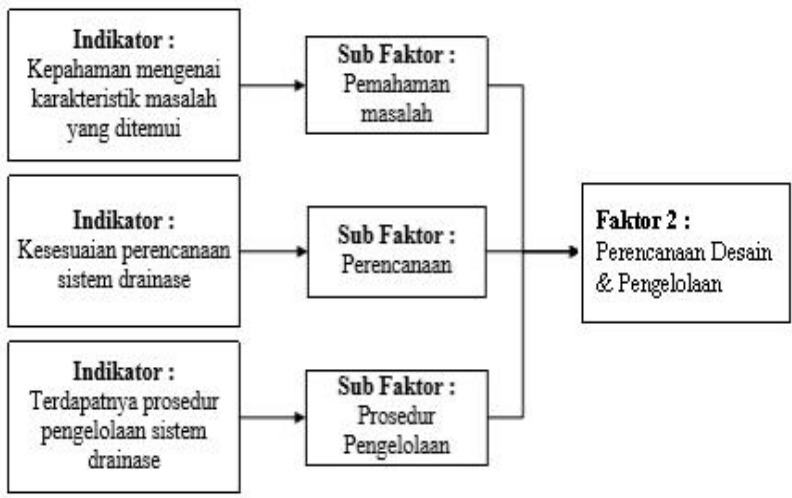

Gambar 3. Skema alur penamaan faktor 2 Sumber : Hasil Analisis

Berdasarkan pembahasan dari beberapa studi literatur di atas maka didapatkan penamaan faktor 3 adalah Komitmen. Faktor komitmen menjadi faktor terakhir dari faktor keberhasilan implementasi sistem drainase sesuai dengan prinsip ZDQ lainnya. Hal ini disebabkan karena tidak semua penanggung jawab sistem drainase di developer apartemen di Surabaya melakukan frekuensi pemeliharaan bangunan drainase secara berkala. Sehingga faktor komitmen muncul pada faktor keberhasilan yang terakhir. Faktor ini tetap menjadi faktor yang fundamental karena setiap penanggung jawab sistem drainase di developer apartemen di Surabaya harus memiliki komitmen yang kuat dalam memperhatikan kebutuhan sistem drainase, kebijakan (regulasi yang berlaku) dan lingkungan sekitar dalam pembangunan apartemennya.

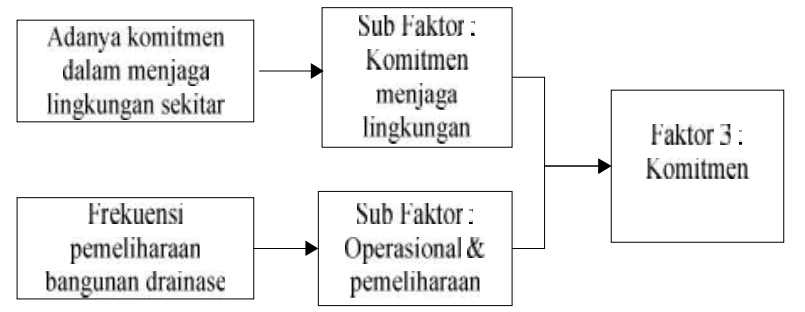

Gambar 4. Skema alur penamaan faktor 3

(Sumber : Hasil Analisis)

\section{Hasil Pembahasan}

Sebelum membangun apartemen pula harus dilengkapi dengan Izin Mendirikan Bangunan (IMB) yang salah satu syaratnya adalah membuat kajian drainase. Kajian drainase ini menghasilkan suatu desain dan usulan teknis dalam membuat sistem dan bangunan drainase untuk pembangunan yang akan dilaksanakan. Menurut salah satu project manager sebuah apartemen yang menjadi responden penelitian ini menyatakan bahwa:"Pada penyusunan kajian drainase untuk IMB Kota Surabaya sudah dipermudah dengan adanya tabel referensi ukuran tampungan yang telah disesuaikan dengan luasan bangunannya".

Tabel referensi ukuran yang dikeluarkan oleh Dinas Bina Marga dan Pematusan Kota Surabaya tesebut telah mengadaptasi prinsip ZDQ karena tampungan tersebut diumpamakan dengan kapasitas serapan air lahan tidak kedap air. Dengan begitu, setiap bangunan yang kedap air, sudah seharusnya menampung terlebih dahulu limpasan air yang dihasilkan sebelum dibuang ke saluran kota. Adapun beberapa project manager yang sempat ditemui menyampaikan bahwa mereka tidak mengetahui mengenai istilah Zero delta $Q$ tetapi mereka mengetahui mengenai tabel referensi tersebut. Hal ini diperkuat juga dengan pernyataan salah satu responden penelitian ini yaitu:'Penyebutan prinsip Zero Delta $Q$ pada kajian drainase pembangunan gedung di Surabaya memang tidak awam. Para pembuat kajian dan para pelaku konstruksi khususnya yang menangani permasalahan drainase, biasanya hanya mengetahui bacaan tabel referensi dari Dinas Bina Marga dan Pematusan Kota Surabaya. Tetapi, bagi para project manager yang sudah lama berkecimpung di dunia sistem drainase bangunan, biasanya memahami akan prinsip ini”. Oleh karena itu pada hasil tingkat kepedulian di penelitian ini ditemukan kejanggalan antara hasil pemahaman dan aplikasinya. Para responden mengaku (melalui kuesioner) bahwa telah mengaplikasikan sistem dan bangunan drainase yang sesuai kebutuhan tetapi mereka tidak mengetahui dan ada pula yang belum pernah mendengar mengenai prinsip ZDQ, hal itu tergantung oleh relativitas pengalaman yang didapatkan atau disiplin ilmu yang pernah diambil sebelumnya.

\section{Simpulan}

Berdasarkan analisis data dan pembahasan yang telah dilakukan pada dapat disimpulkan sebagai berikut:

1. Tingkat kepedulian (awereness) para penanggung jawab konstruksi di developer apartemen yang berada di Surabaya dapat disimpulkan bahwa para penanggung jawab konstruksi di developer apartemen Surabaya telah membuat dan melaksanakan sistem dan bangunan drainase secara tepat walaupun tidak mengetahui prinsipprinsip ZDQ.

2. Dari 11 indikator awal yang mempengaruhi keberhasilan implementasi sistem drainase berdasarkan prinsip ZDQ dapat direduksi menjadi 8 indikator dan di kelompokan kedalam 3 faktor. (a) Faktor pertama yang diberi nama dengan pengelolaan drainase terdiri dari 3 indikator yaitu ketersediaan pengelola sistem drainase, frekuensi evaluasi sistem drainase, dan kelancaran sistem drainase mampu memberikan pengaruh sebesar $52,097 \%$ terhadap 
keberhasilan implementasi sistem drainase. (b) Faktor kedua terdiri dari 3 indikator yaitu kepemahaman mengenai karakteristik masalah yang ditemui, kesesuaian perencanaan sistem drainase dan terdapatnya prosedur pengelolaan sistem drainase kemudian dikelompokan kedalam faktor perencanaan desain dan pengelolaan, mampu memberi pengaruh sebesar $14,995 \%$ terhadap keberhasilan implementasi sistem drainase. (c) Faktor ketiga terdiri dari dua indikator yaitu adanya komitmen dalam menjaga lingkungan sekitar dan frekuensi pemeliharaan bangunan drainase, mampu memberikan pengaruh sebesar $12,953 \%$ terhadap keberhasilan implementasi sistem drainase dan dikelompokan kedalam faktor komitmen.

\section{Daftar Pustaka}

[1] A. Maryono, Pembangunan sungai: dampak dan restorasi sungai. Magister Sistem Teknik, Program Pascasarjana, Universitas Gadjah Mada, 2003.

[2] R. H. Indriatmoko, "Penerapan Prinsip Zero Delta Q dalam Pembangunan Wilayah,” J. AIR Indones., vol. 6, no. 1, pp. 77-83, 2010.

[3] G. Tanuwidjaja and J. M. Widjaya, "Integrasi Tata Ruang dan Tata Air Untuk Mengurangi Banjir di Surabaya," in Seminar Nasional Aristektur (di) Kota " Hidup dan berkehidupan di Surabaya, 2010.

[4] A. Widarjono, Analisis Statistika Multivariat Terapan I. Yogyakarta: UPP STIM YKPN, 2010.

[5] D. Garsia, B. Sujatmoko, and R. Rinaldi, "Analisis Kapasitas Tampungan Embung Bulakan untuk Memenuhi Kekurangan Kebutuhan Air Irigasi di Kecamatan Payakumbuh Selatan," J. Online Mhs. Bid. Tek. dan Sains, vol. 1, no. 1, pp. 1-15, Aug. 2014.

[6] I. Suryanti, I. N. Norkem, and I. G. B. Sila Dharma, "Kinerja Sistem Jaringan Drainase Kota Semarapura di kabupaten Klungkung," J. Spektran, vol. 1, no. 2, pp. 30-34, 2013.

[7] S. Andayani, B. E. Yuwono, and S. -, "Indikator Tingkat Layanan Drainase Perkotaan," J. Tek. Sipil, vol. 11, no. 2, Apr. 2012.

[8] M. Taufiq, "Kedudukan dan prosedur AMDAL dalam Pengelolaan Lingkungan," WIGA-Jurnal Penelit. Ilmu Ekon., vol. 1, no. 2, pp. 21-42, 2011. 
